\title{
New combinations in the genus Vachellia (Fabaceae: Mimosoideae) from Australia
}

\author{
Phillip G. Kodela and Peter G. Wilson
}

National Herbarium of New South Wales, Botanic Gardens Trust, Mrs Macquaries Road, Sydney NSW 2000, Australia

\begin{abstract}
Based on the evidence that the genus Acacia sens. lat. is polyphyletic and the acceptance that the major groups warrant generic status, and because the name Acacia has been conserved with a new type, the following new combinations in Vachellia Wight \& Arn. are necessary for Australian taxa formerly included in Acacia subg. Acacia: Vachellia bidwillii (Benth.) Kodela, V. clarksoniana (Pedley) Kodela, V. ditricha (Pedley) Kodela, V. douglasica (Pedley) Kodela, V. pachyphloia (W.Fitzg.) Kodela and V. pachyphloia subsp. brevipinnula (Tindale \& Kodela) Kodela, V.pallidifolia (Tindale) Kodela, V. suberosa (A.Cunn. ex Benth.) Kodela, V. sutherlandii (F.Muell.) Kodela, and V. valida (Tindale \& Kodela) Kodela. Vachellia farnesiana (L.) Wight \& Arn., a pre-European introduction to Australia, has previously been transferred to the genus. Acacia nilotica (L.) Delile has been left for the attention of other researchers more familiar with this taxon, its synonymy and its various subspecies.
\end{abstract}

\section{Introduction}

Synopses of recent morphological and molecular studies showing that the genus Acacia sens. lat. is polyphyletic and requires division into at least five genera are provided by Maslin et al. (2003, 2003a). At the July 2005 International Botanical Congress in Vienna a conservation proposal by Orchard and Maslin (2003) was endorsed, resulting in the retypification of the genus Acacia ( $\mathrm{McNeill} \mathrm{et} \mathrm{al.2005).} \mathrm{This} \mathrm{decision} \mathrm{results} \mathrm{in} \mathrm{the} \mathrm{type}$ of the genus being changed from the African species Acacia nilotica (L.) Delile to the Australian species Acacia penninervis Sieber ex DC. As a result of this, if the genus is split, Vachellia Wight \& Arn. is the earliest available name applicable to species formerly included in Acacia subg. Acacia, while the name Acacia is retained for species of the former Acacia subg. Phyllodineae, the majority of which occur in Australia.

In Australia there are eleven species of the former Acacia subg. Acacia (Pedley 2002); nine of these are endemic to tropical Australia. Acacia farnesiana (L.) Willd., which is widespread through the tropics in central America, Africa and Asia, probably arrived in Australia prior to European settlement (Kodela \& Tindale 2001, Pedley 2002). The more recent introduction, Acacia nilotica subsp. indica (Benth.) Brenan (Fig. 1), which 
is naturalised in Queensland and the Northern Territory, is now known to show genetic diversity in Australia indicating that more than one infraspecific taxon may be present here (Wardill et al. 2006).

Acacia farnesiana is the type of the genus Vachellia, so the combination Vachellia farnesiana (L.) Wight \& Arn. (Prodr. Fl. Ind. Orient. 272, 1834) already exists. Plants of this taxon in Australia seem all to be referable to var. farnesiana (Pedley 2002, Kodela pers. obs., Seigler pers. comm.) (Fig. 2). Combinations in Vachellia for New World taxa of the former Acacia subg. Acacia have recently been made by Seigler and Ebinger (2006).

New combinations in Vachellia are made here for the endemic Australian taxa so that these names are available for use in floras and checklists. No combination, however, is made for Acacia nilotica (L.) Delile, which presents more difficulties (see Wardill et al. 2006) and has been left for the attention of other researchers more familiar with this taxon, its synonymy and its various subspecies.

\section{New Combinations}

1. Vachellia bidwillii (Benth.) Kodela, comb. nov. (Fig. 3)

Basionym: Acacia bidwillii Benth., Linnaea 26: 629 (1855).

Holotype: Queensland: 'Ad Wide-Bay, Australiae boreali-orientalis (Bidwill)' (K).

A. leptoclada var. (?) polyphylla Benth., Fl. Austral. 2: 416 (1864).

Holotype: 'East Coast' [Queensland], R. Brown [Bennett sheet No. 4331], 1802-5 (K; photo NSW).

A. bidwillii var. bidwillii, Fl. Austral. 2: 420 (1864), autonym.

A. bidwillii var. polytricha Domin, Biblioth. Bot. 89: 273 (1926).

Type citation: 'Nord-Queensland: Savannenwälder bei Mungana (DomIN II. 1910)' Holotype: Queensland: in xerodrymio apud opp. Mungana, K. Domin '5148', Feb 1910 (PR 527948).

\section{Vachellia clarksoniana (Pedley) Kodela, comb. nov.}

Basionym: Acacia clarksoniana Pedley, Austrobaileya 6: 184, fig. 1 A, B (2002).

Holotype: Queensland: 3.9 km from 'New Dixie' homestead, J.R. Clarkson 3585, 15 Oct 1980 (BRI). Isotypes: ILL, K, MEL, MO, NSW, PERTH, PR, QRS.

3. Vachellia ditricha (Pedley) Kodela, comb. nov. (Fig. 4)

Basionym: Acacia ditricha Pedley, Austrobaileya 1: 307 (1980).

Holotype: Queensland: Kowanyama Aboriginal Reserve on the Mitchell River, B. Alpher, Dec 1977 (BRI). 


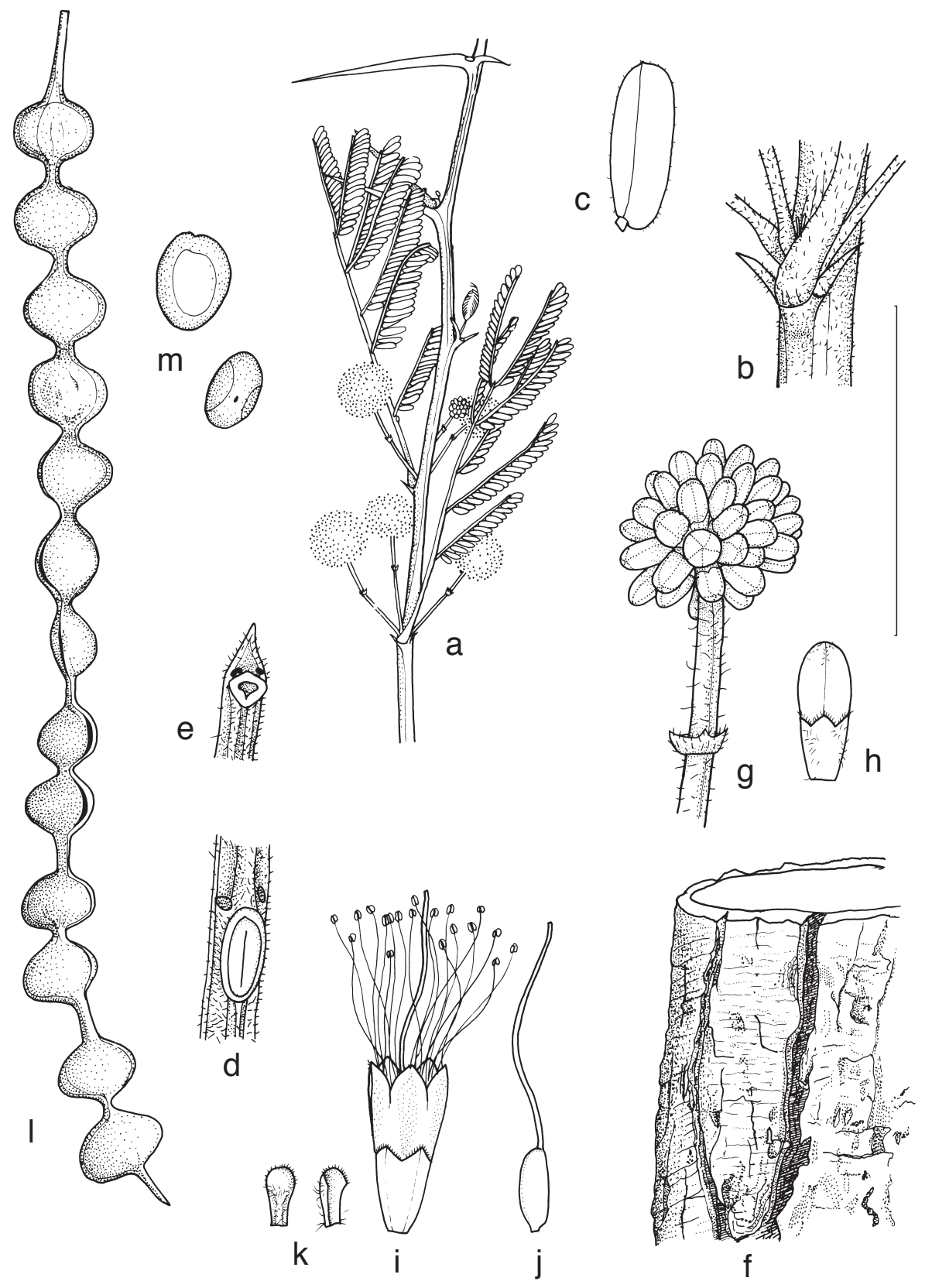

Fig. 1. 'Acacia' nilotica subsp. ?indica. a, branchlet with leaves and inflorescences; $\mathbf{b}$, leaf base and stipular spines; c, pinnule; $\mathbf{d}$, petiolar gland; e, gland at apex of leaf rachis; $\mathbf{f}$, bark; $\mathbf{g}$, inflorescence in bud; h, flower bud; i, flower; $\mathbf{j}$, gynoecium; $\mathbf{k}$, bracteoles; $\mathbf{l}$, pod; $\mathbf{m}$, seeds. a-e, i-k, Newman 565 (NSW); f, Coveny 6925 \& Hind (NSW); g, h, l, m, C.E.F. Allen (NSW271068). Scale bar $=0.6$ $\mathrm{cm}(\mathrm{d}, \mathrm{e}, \mathrm{h}-\mathrm{k}), 1 \mathrm{~cm}$ (c), $1.2 \mathrm{~cm}(\mathrm{~b}, \mathrm{~g}), 3 \mathrm{~cm}(\mathrm{~m}), 6 \mathrm{~cm}$ (a, f, l). 
4. Vachellia douglasica (Pedley) Kodela, comb. nov.

Basionym: Acacia douglasica Pedley, Austrobaileya 6: 181, fig. 1 C, D (2002).

Holotype: Northern Territory: 0.5 km W of Douglas River, M. Parker 508, 23 Oct 1974 (BRI). Isotypes: CANB, DNA, NSW.

Acacia 'Douglas R.', C.R. Dunlop et al., Fl. Darwin Region 2: 20, fig. 4 (1995).

Note: Pedley (2002) suggested that Tindale and Kodela (1996) included A. douglasica as part of A. ditricha but this was not the case. Although specimens of the then undescribed species $A$. douglasica were known at the time and were considered as a possible variant of $A$. ditricha they were neither included in the description of $A$. ditricha nor cited in the Tindale and Kodela (1996) paper. The Douglas River taxon was later addressed in the Flora of Australia (Kodela \& Tindale 2001: 202) under Acacia bidwillii.

\section{Vachellia pachyphloia (W.Fitzg.) Kodela, comb. nov.}

Basionym: Acacia pachyphloia W.Fitzg. in J.H. Maiden, J. \& Proc. Roy. Soc. New South Wales 51: 116 (1917).

Type citation: 'Slopes of Bold Bluff; hills near C. 92, in proximity to the Synnott Range; hills by the Charnley and Calder Rivers (W.V.F.)'

Lectotype (fide Tindale \& Kodela 1996: 311): Western Australia: near Synnott [Synnot] Range, W.V. Fitzgerald 1267, July 1905 (NSW). Isolectotype: PERTH.

Residual syntypes [paralectotypes]: slopes of Bold Bluff, W.V. Fitzgerald; hills by the Charnley and Calder Rivers, W.V.Fitzgerald (n.v., location unknown).

5a. Vachellia pachyphloia (W.Fitzg.) Kodela subsp. pachyphloia

5b. Vachellia pachyphloia subsp. brevipinnula (Tindale \& Kodela) Kodela, comb. nov.

Basionym: Acacia pachyphloia subsp. brevipinnula Tindale \& Kodela, Austral. Syst. Bot. 9: 314, fig. 3 (1996).

Holotype: Western Australia: $26 \mathrm{~km} \mathrm{~N}$ of turnoff to Mitchell Falls along road to Port Warrender, M. McDonald 336, 14 June 1987 (NSW). Isotype: PERTH.

6. Vachellia pallidifolia (Tindale) Kodela, comb. nov. (Fig. 5)

Basionym: Acacia pallidifolia Tindale, Telopea 1: 82 (1975), based on Acacia pallida F. Muell., J. Linn. Soc., Bot. 3: 147 (1859), partim, non Humb. et Bonpl. ex Willd. (1806).

Lectotype (fide Tindale, loc. cit.): Northern Territory: Fitzmaurice River, 'arbuscula in campis apricis', F. Mueller 76, 75, Oct 1855 (MEL). Isolectotype: NSW.

Residual syntypes [paralectotypes]: McAdam Range, F. Mueller 75, Oct 1855 (K, PERTH).

Acacia turbata Pedley, Austrobaileya 6: 180 (2002).

Holotype: Northern Territory: E of Mary River, S.T. Blake 17095, 29 Sep 1946 (BRI). Isotype: NSW. 


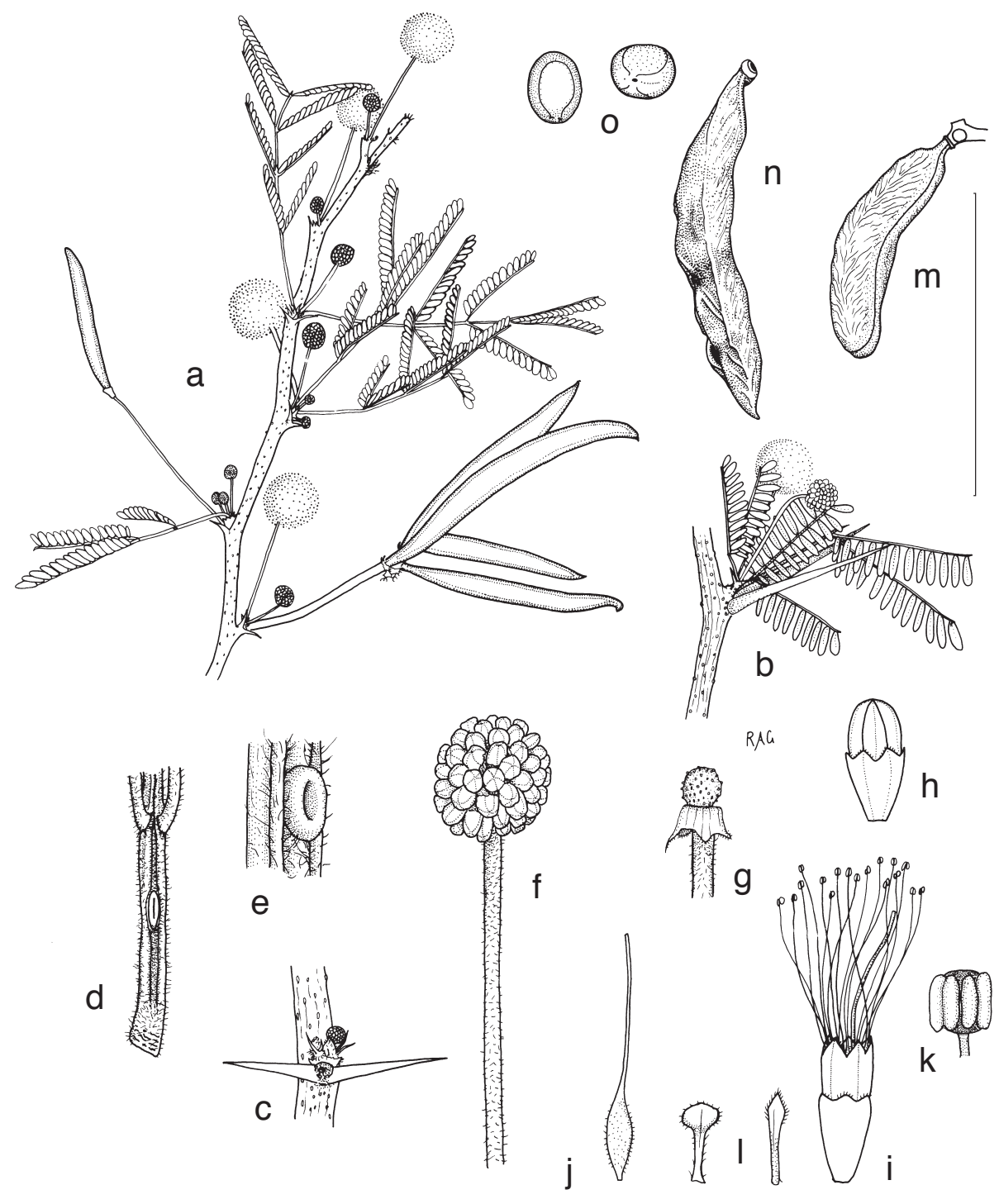

Fig. 2. Vachellia farnesiana var. farnesiana. a, branchlet with leaves, inflorescences and immature pods; b, leaves, inflorescences and stipular spines; c, stipular spines; d, petiole showing gland; e, petiolar gland; $\mathbf{f}$, inflorescence in bud; $\mathbf{g}$, involucel of united bracts at apex of peduncle (usually hidden by flowers); $\mathbf{h}$, flower bud; $\mathbf{i}$, flower; $\mathbf{j}$, gynoecium; $\mathbf{k}$, anther; $\mathbf{l}$, bracteoles; $\mathbf{m}$, n, pods; o, seeds. a, f, h-j, l, Coveny 6572 \& Powell (NSW); b, d, Milvain (NSW108509); c, m, K. Moore (NSW108510); e, G.M. Cunningham 704 (NSW); g, Milthorpe 3821 (NSW); k, Rodd s.n. (NSW70825), n, o, Coveny 6522 \& Powell (NSW). Scale bar $=0.075 \mathrm{~cm}(\mathrm{k}), 0.4 \mathrm{~cm}(\mathrm{e}), 0.6$ $\mathrm{cm}(\mathrm{h}-\mathrm{j}, \mathrm{l}), 1.2 \mathrm{~cm}(\mathrm{~d}, \mathrm{f}, \mathrm{g}), 2 \mathrm{~cm}(\mathrm{c}), 3 \mathrm{~cm}(\mathrm{o}), 6 \mathrm{~cm}$ (a, b, m, n). 


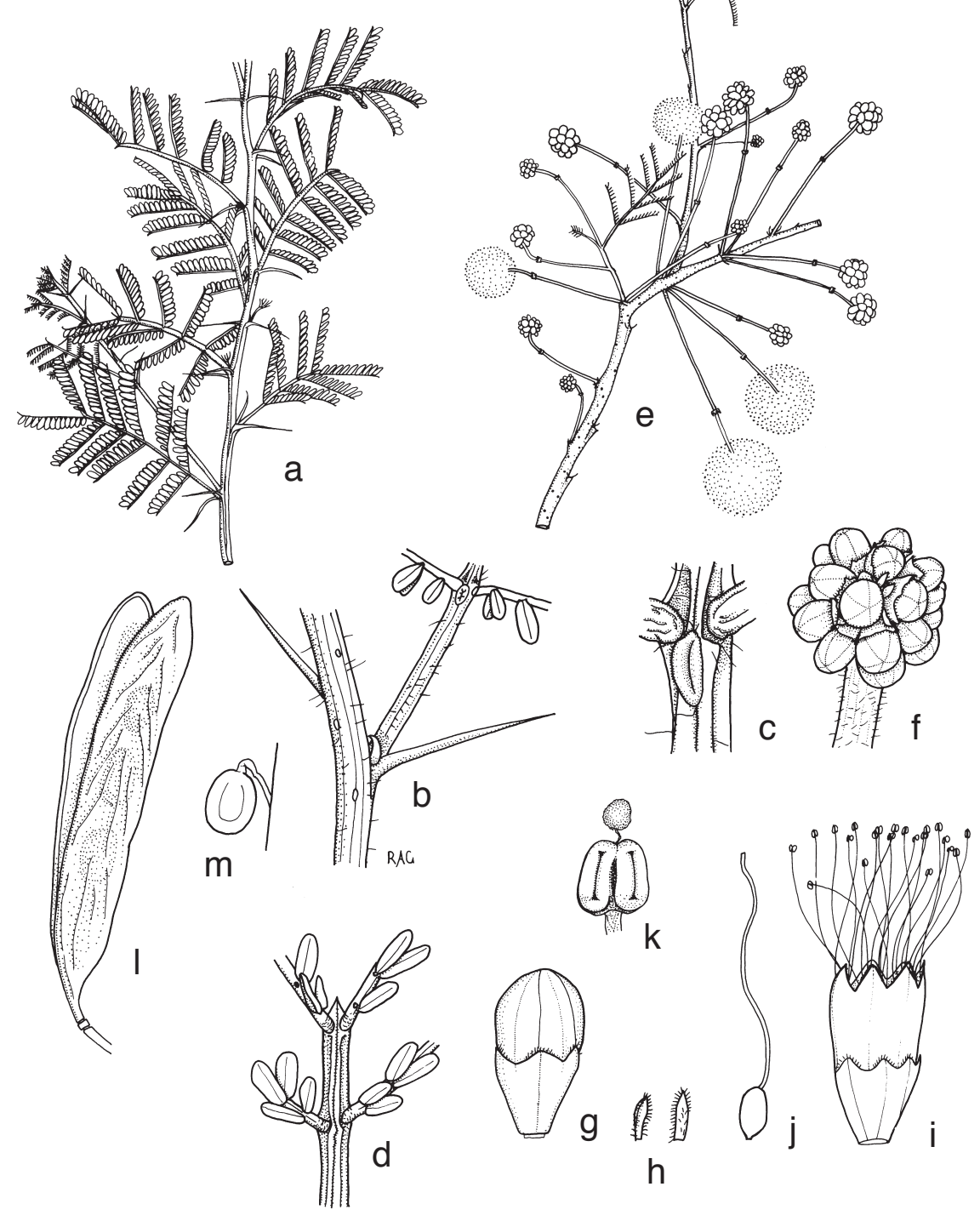

Fig. 3. Vachellia bidwillii. a, branchlet with leaves; b, petiole and stipular spines; $\mathbf{c}$, petiolar gland; d, apex of leaf rachis; e, inflorescences; $\mathbf{f}$, inflorescence in bud; $\mathbf{g}$, flower bud; $\mathbf{h}$, bracteoles; i, flower; j, gynoecium; k, anther; l, pod; m, seed. a-l, Tindale (NSW52690); m, Coveny 6876 \&Hind (NSW). Scale bar $=0.1 \mathrm{~cm}(\mathrm{k}), 0.4 \mathrm{~cm}(\mathrm{c}), 0.6 \mathrm{~cm}(\mathrm{~g}-\mathrm{j}), 1 \mathrm{~cm}(\mathrm{~b}, \mathrm{~d}), 1.2 \mathrm{~cm}(\mathrm{f})$, $4 \mathrm{~cm}(\mathrm{~m}), 6 \mathrm{~cm}(\mathrm{a}, \mathrm{e}, 1)$. 


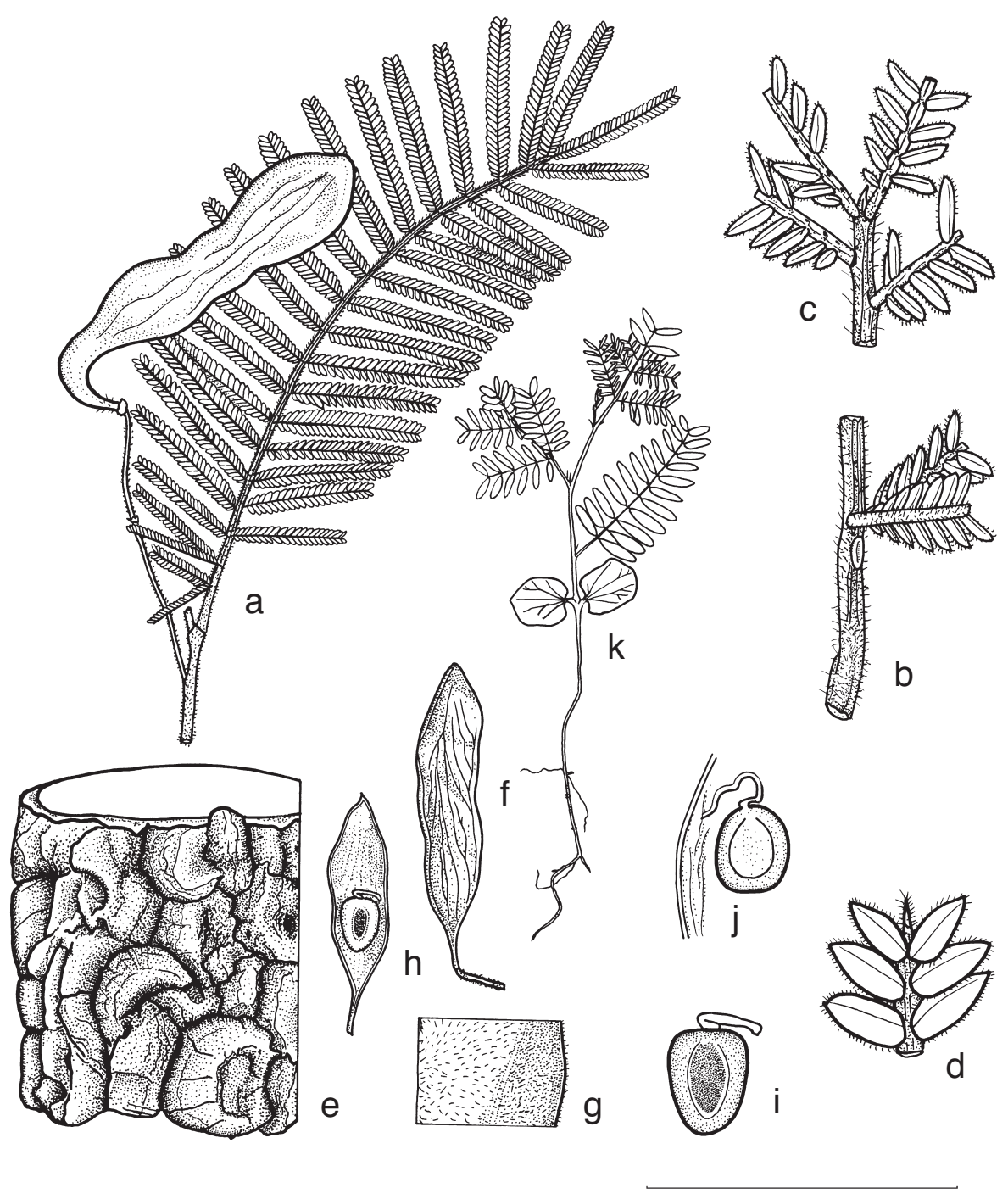

Fig. 4. Vachellia ditricha. a, apex of branchlet with leaf and pod; $\mathbf{b}$, base of leaf showing petiolar gland; c, apex of leaf; $\mathbf{d}$, apex of pinna; e, bark; $\mathbf{f}$, pod; $\mathbf{g}$, section of pod showing indumentum on outer surface; h, seed in pod; i, j, seeds; k, seedling. a, Maconochie 206 (DNA); b-d, j, Perry 2833 \& Lazarides (CANB); e-i, Jacobs 1732 (NSW); k, AZRI (NT sheet), seedling grown from seed of N. McK. Henry 7 (NT31554). Scale bar $=0.5 \mathrm{~cm}(\mathrm{~g}), 0.6 \mathrm{~cm}(\mathrm{~d}), 1.2 \mathrm{~cm}(\mathrm{~b}, \mathrm{c}), 3 \mathrm{~cm}$ (i), $4 \mathrm{~cm}$ (a, j), $6 \mathrm{~cm}$ (e, f, h, k). 
Note: The possible type material of Acacia pallida F.Muell., nom. illeg., includes two different taxa. However, there have been two different interpretations of this material that have resulted in the replacement name A. pallidifolia Tindale being applied to each of these two different taxa. We have followed the concept adopted by Tindale (1975) while Pedley (2002) applies this name to the taxon named A. valida by Tindale and Kodela (1996). To further add to the confusion, Pedley (2002) reverses Tindale's application of the name Acacia pallidifolia, renaming her species concept as A. turbata Pedley. The species concept originally adopted by Tindale (1975), and which was in use for almost 30 years, has now been challenged by Pedley's (2002) rejection of her lectotypification. While Pedley's view has merit, we suggest that nomenclatural stability is not well served by his approach because it would lead to a confusing reversal of names. A case for conservation of the name A. pallidifolia in the sense of Tindale (1975) is in preparation and will be submitted for consideration by the Committee for Spermatophyta.

7. Vachellia suberosa (A.Cunn. ex Benth.) Kodela, comb. nov. (Fig. 6)

Basionym: Acacia suberosa A.Cunn. ex Benth., London J. Bot. 1: 499 (1842).

Lectotype (fide Kodela, Fl. Australia 11A: 642, 2001): Western Australia: Careening Bay, North West Coast, 3rd Voyage of 'Mermaid', A. Cunningham 300, Sep 1820 [larger, right-hand element] (K). Isolectotype: BM.

Residual syntypes [paralectotypes]: Western Australia: Encounter Cove, Vansittart Bay, North West Coast, 2nd Voyage of 'Mermaid', A. Cunningham 488, Oct 1819 (BM, K).

8. Vachellia sutherlandii (F.Muell.) Kodela, comb. nov. (Fig. 7)

Basionym: Albizia sutherlandi F.Muell., Fragm. 6: 22 (1867). Acacia sutherlandii (F.Muell.) F.Muell. (as 'Sutherlandi'), Iconogr. Austral. Acacia Dec. 12: [pl. 8] (June 1888).

Holotype: Queensland: Flinders River, J. Sutherland 114 (MEL).

Acacia melaleucoides F.M.Bailey, Proc. Roy. Soc. Queensland 5: 121 (Sep 1888).

Holotype: Queensland: South-eastern slope of Newcastle Range, between Georgetown and Junction Ck, R.C. Burton (?BRI, n.v.)

\section{Vachellia valida (Tindale \& Kodela) Kodela, comb. nov.}

Basionym: Acacia valida Tindale \& Kodela, Austral. Syst. Bot. 9: 307, fig. 1 (1996).

Holotype: Northern Territory: Mathison Ck, c. $91.5 \mathrm{~km}$ W of Katherine on the Victoria Hwy, M.D. Tindale 10101, P. Munns \& R. Turley, 2 Aug 1989 (NSW). Isotypes: AD, BRI, CANB, DNA, K, MEL, MO, PERTH.

A. pallida F.Muell., J. Linn. Soc., Bot. 3: 147 (1859), partim, non Humb. et Bonpl. ex Willd. (1806).

A. bidwillii Benth. var. (?) major Benth. (as 'Bidwilli'), Fl. Austral. 2: 421 (1864).

Holotype: (Dry) ridges of the Victoria River, F. Mueller 76, Nov 1855 (MEL). Isotype: $\mathrm{K}$. 


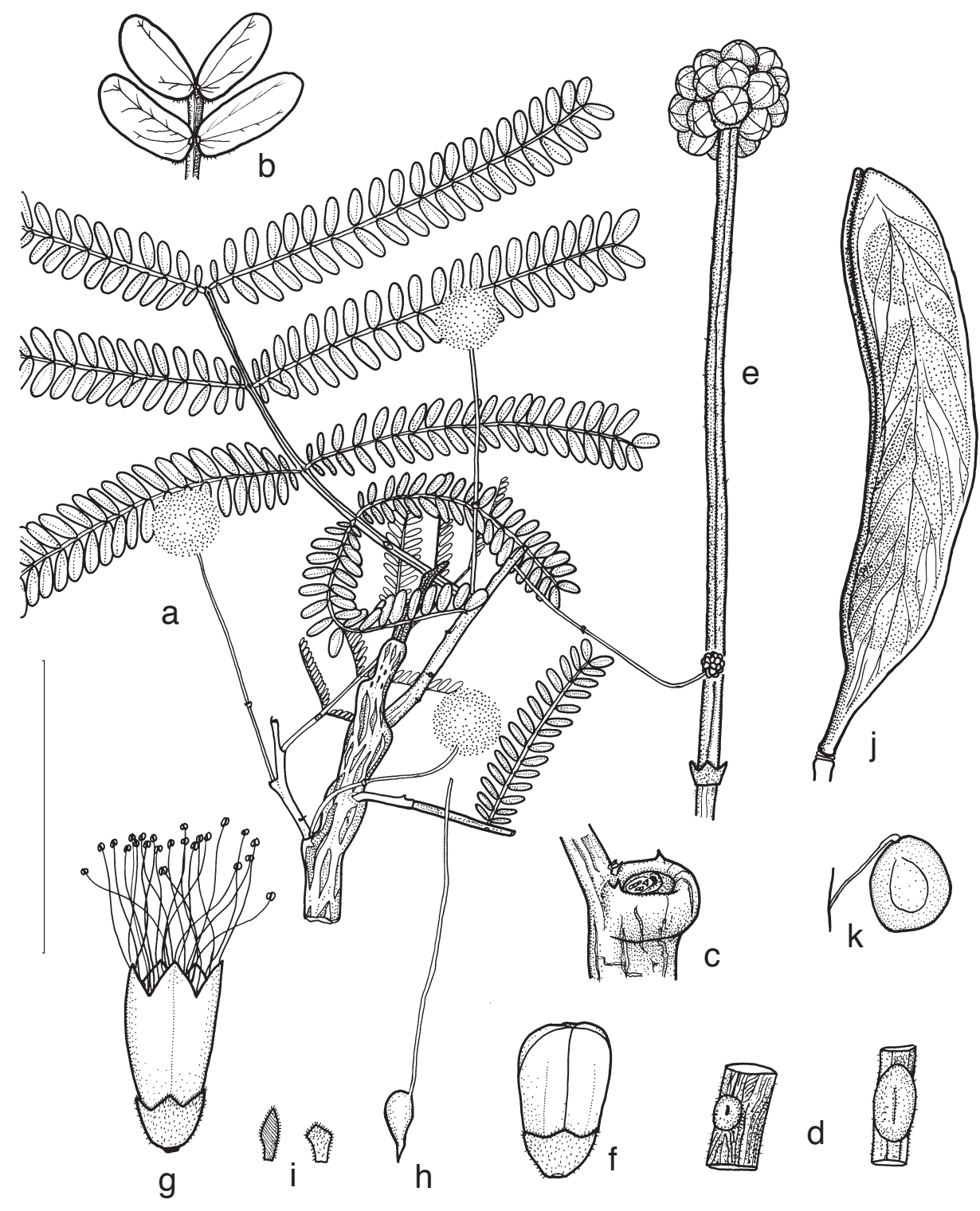

Fig. 5. Vachellia pallidifolia. a, branchlet with leaves and inflorescences; $\mathbf{b}$, pinnules at apex of pinna; c, leaf scar showing small stipular spines; d, leaf glands; e, inflorescence in bud; f, flower bud; g, flower; h, gynoecium; i, bracteoles; $\mathbf{j}$, pod; $\mathbf{k}$, seed. a, b, d-i, M. White MR13(CANB); c, j, k, Blake 17095 (NSW). Scale bar = $0.4 \mathrm{~cm}(\mathrm{f}), 0.6 \mathrm{~cm}(\mathrm{~g}-\mathrm{i}), 0.66 \mathrm{~cm}(\mathrm{~d}), 1.33 \mathrm{~cm}$ (e), $2 \mathrm{~cm}(\mathrm{~b}, \mathrm{c}), 4 \mathrm{~cm}(\mathrm{k}), 6 \mathrm{~cm}(\mathrm{a}, \mathrm{j})$ 


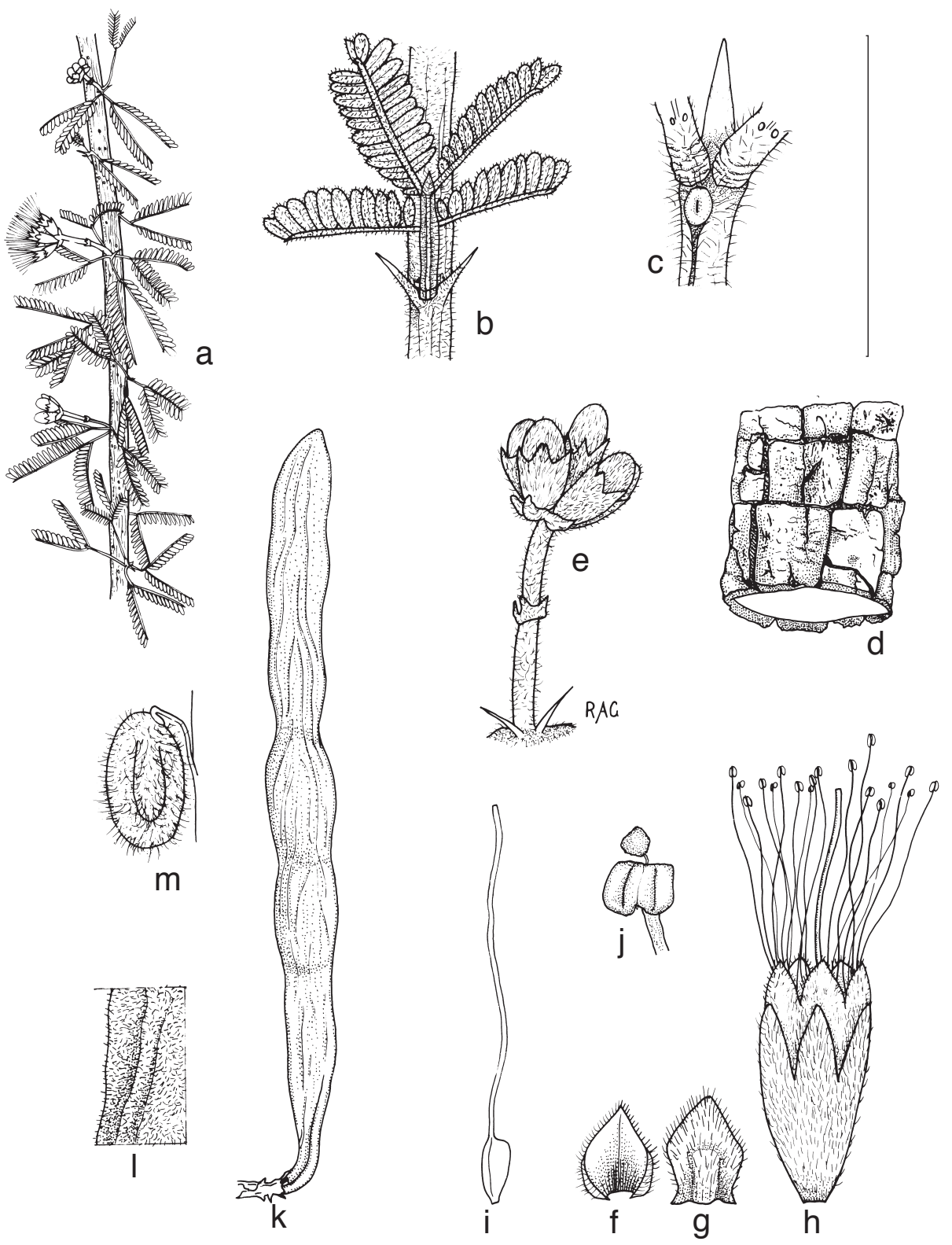

Fig. 6. Vachellia suberosa. a, branchlet with leaves and inflorescences; b, leaf and stipular spines; c, gland at apex of leaf rachis; d, bark; e, inflorescence in bud; $\mathbf{f}$, inner surface of bracteole; $\mathbf{g}$, outer surface of bracteole; $\mathbf{h}$, flower; $\mathbf{i}$, gynoecium; $\mathbf{j}$, anther; $\mathbf{k}$, pod; $\mathbf{l}$, section of pod showing indumentum on outer surface; m, seed. a, c, e, j, Lazarides 7744 (NSW); b, Lazarides 3104 (NSW); d, Maconochie 1183 (NSW); f-i Byrnes 2228 (NSW); k-m, Lazarides 6515 (NSW). Scale bar $=0.1$ $\mathrm{cm}(\mathrm{j}), 0.3 \mathrm{~cm}(\mathrm{l}), 0.4 \mathrm{~cm}(\mathrm{c}), 0.6 \mathrm{~cm}(\mathrm{f}-\mathrm{i}), 1.5 \mathrm{~cm}(\mathrm{e}), 2 \mathrm{~cm}(\mathrm{~b}), 4 \mathrm{~cm}(\mathrm{~m}), 6 \mathrm{~cm}(\mathrm{a}, \mathrm{d}, \mathrm{k})$. 


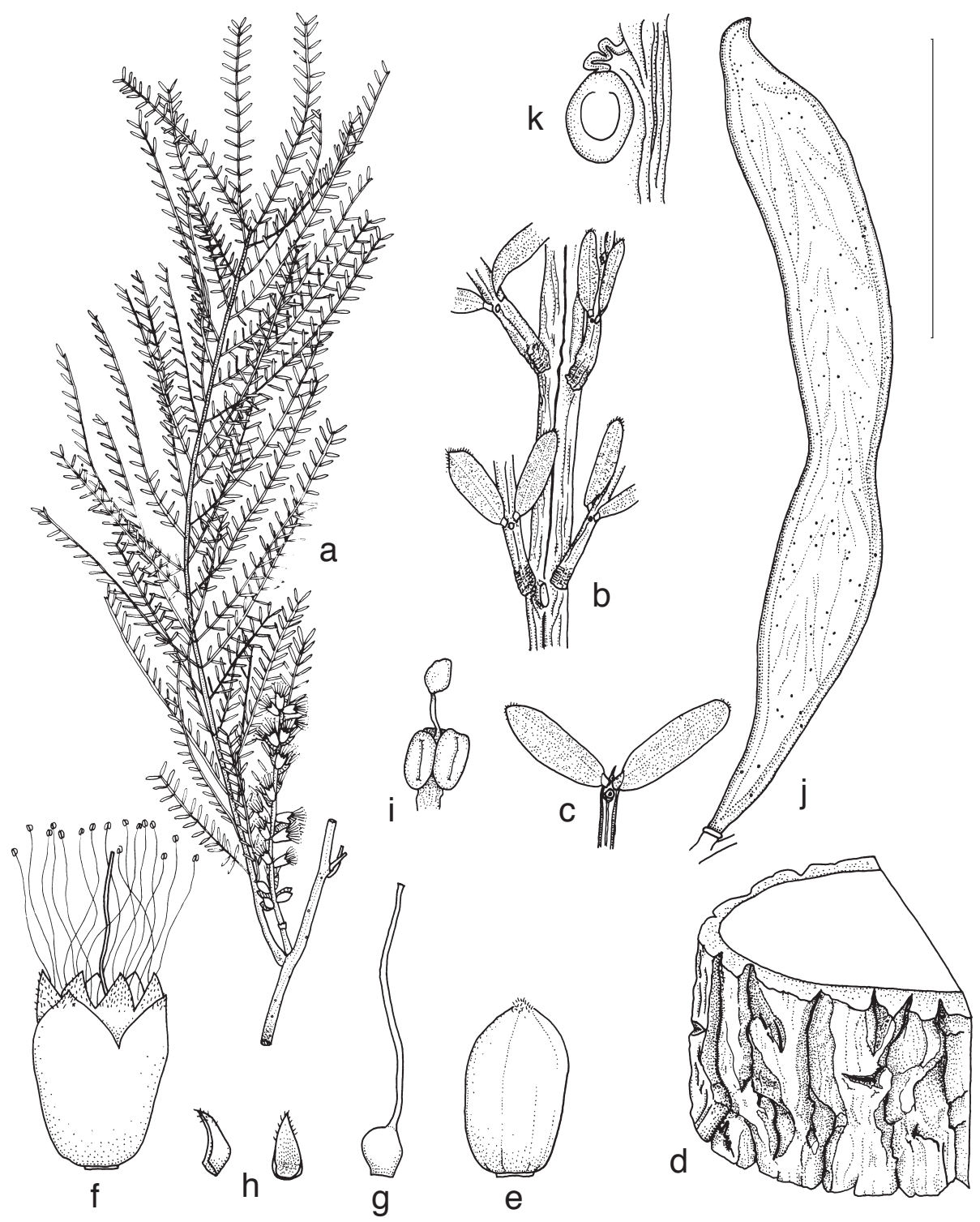

Fig. 7. Vachellia sutherlandii. a, part of branchlet with leaf and inflorescence; $\mathbf{b}$, part of leaf rachis showing petiolar gland; c, apex of pinna; d, bark; e, flower bud; f, flower; $\mathbf{g}$, gynoecium; h, bracteoles; i, anther; $\mathbf{j}$, pod; $\mathbf{k}$, seed. a-c, e-i, Waterhouse s.n. (NSW108060); d, Jacobs 1374 (NSW); j, k, Hind $1069 \&$ Ingram (NSW). Scale bar $=0.1 \mathrm{~cm}(\mathrm{i}), 0.6 \mathrm{~cm}(\mathrm{c}, \mathrm{e}-\mathrm{h}), 1 \mathrm{~cm}(\mathrm{~b}), 4 \mathrm{~cm}$ (k), $6 \mathrm{~cm}$ (a, d, j). 
Note: Pedley (2002) treated A. valida as a synonym of Acacia pallidifolia. Correct application of the latter name is contingent upon resolution of the issue of its typification, as discussed above.

\section{Acknowledgments}

We are grateful for comments and advice on the Acacia pallida typification issue provided in 2000 by Drs Mary Tindale and Jim Ross (MEL), as well as earlier advice provided to Dr Tindale by the late Dr L.A.S. Johnson. Many thanks also to Bruce Maslin and Paul Wilson for constructive comments on this manuscript. Dave Seigler kindly provided details of his recently published paper and other information. Access to collections was generously provided by BM, K and MEL. Illustrations were by Robin Griffiths and made available by Dr Tindale. Catherine Wardrop and Julia Sideris assisted with the final preparation of the illustrations and scale bars.

\section{References}

Kodela PG \& Tindale MD (2001) Acacia subg. Acacia. Flora of Australia 11A: 196-207.

Maslin BR, Miller JT \& Seigler DS (2003) Overview of the generic status of Acacia (Leguminosae: Mimosoideae). Australian Systematic Botany 16: 1-18.

Maslin BR, Orchard AE \& West JG (2003a) Nomenclatural and classification history of Acacia (Leguminosae: Mimosoideae), and the implications on generic subdivision. Paper on Worldwidewattle website at http://www.worldwidewattle.com/infogallery/taxonomy/ nomen-class.pdf

McNeill J, Stuessy TF, Turland NJ \& Hörandl E (2005) XVII International Botanical Congress: preliminary mail vote and report of Congress action on nomenclature proposals. Taxon 54 (4): 1057-1064.

Orchard AE \& Maslin BR (2003) Proposal to conserve the name Acacia (Leguminosae: Mimosoideae) with a conserved type. Taxon 52: 362-363.

Pedley L (2002) A conspectus of Acacia subg. Acacia in Australia. Austrobaileya 6: 177-186.

Seigler DS \& Ebinger JE (2006) New combinations in the genus Vachellia (Fabaceae: Mimosoideae) from the New World. Phytologia 87 (3): 139-178. [dated Dec 2005, published 5 Jan 2006]

Tindale MD \& Kodela PG (1996) Acacia valida (Fabaceae, Mimosoideae), a new species from Western Australia and the Northern Territory, as well as the typification and revision of $A$. pachyphloia. Australian Systematic Botany 9: 307-317.

Wardill TJ, Graham GC, Zalucki M, Palmer WA, Playford J \& Scott KD (2006) The importance of species identity in the biological control process: identifying the subspecies of Acacia nilotica (Leguminosae: Mimosoideae) by genetic distance and the implications of biological control. Journal of Biogeography 32: 2145-2159.

Manuscript received 20 February 2006, accepted 1 March 2006 